\title{
Stimulation of protein synthesis and breakdown by vaccination
}

\author{
PETER J GARLICK, MARGARET A MCNURLAN, \\ JOHN C WATERLOW
}

\section{Summary and conclusions}

Six normal volunteers were vaccinated against typhoidcholera. ${ }^{15} \mathrm{~N}$-Glycine was injected the morning after vaccination. The injection was repeated three to six days and 10 days later. All subjects ate the same diet on each occasion. Excretion of ${ }^{15} \mathbf{N}$ in urinary ammonia and total urinary excretion of nitrogen, ammonia, and creatinine were determined after each injection of istope. Urinary excretion of ${ }^{15} \mathbf{N}$ was used to calculate rates of whole-body protein turnover.

Total urinary nitrogen and ammonia excretions showed no appreciable change on all three days. Creatinine excretion was significantly higher the day after vaccination than on the other two days $(p<0.05)$. Rates of protein turnover were also significantly higher on this day: a $37 \%$ increase in synthesis and $55 \%$ increase in degradation were noted.

These results show that during the reaction to vaccination there was a stimulation of whole-body protein metabolism that is similar to that produced by sepsis.

\section{Introduction}

Body protein is continuously broken down and renewed (protein turnover); hence protein can be lost or gained through changes in either synthesis or breakdown. Serious infection results in loss of body protein, ${ }^{1}$ but little is known of the changes in protein synthesis and breakdown that cause this. One study showed that sepsis gave rise to rates of whole-body protein synthesis and breakdown in excess of those found in normal subjects. ${ }^{2}$ This contrasts with those results from studies in which postoperative trauma apparently depressed the rate of protein synthesis. ${ }^{34}$

Vaccination can cause fever and loss of body nitrogen, ${ }^{5}$ and results in a temporary impairment of growth in children. ${ }^{6} \mathrm{We}$ have therefore measured whole-body protein turnover in normal adult volunteers who were given a vaccination against typhoidcholera. Rates of protein turnover were determined by giving a single dose of ${ }^{15} \mathrm{~N}$-glycine and measuring the subsequent excretion of ${ }^{15} \mathrm{~N}$ in urinary ammonia. This method is simple; employs the harmless, stable isotope ${ }^{15} \mathrm{~N}$; and is particularly suitable for repeated studies in young volunteers.

\section{Subjects and methods}

SUBJECTS

Six staff members (five men and one woman) aged $29-40$ and weighing $58-72 \mathrm{~kg}$ volunteered for vaccination. All were within $10 \%$

Clinical Nutrition and Metabolism Unit, Department of Human Nutrition, London School of Hygiene and Tropical Medicine, London NW1 2PE

PETER J GARLICK, MA, PHD, MRC external scientific staff and honorary senior lecturer

MARGARET A MCNURLAN, BS, research office

EDWARD B FERN, MIBIOL, PHD, research officer

ANDREW $M$ TOMKINS, $M B$, MRCP, senior lecturer and honorary consultant physician

JOHN C WATERLOW, SCD, FRCP, professor of human nutrition
EDWARD B FERN, ANDREW M TOMKINS,

of ideal body weight, and none suffered from any known metabolic disorder. ${ }^{15} \mathrm{~N}$-Glycine was administered in accordance with a protocol approved by the ethical committee.

\section{PROTOCOL}

Experiments were performed on three separate days: day $A$, the morning after vaccination; day $\mathrm{B}$, three to six days after day $\mathrm{A}$; and day $C, 10$ days after day $A$. On days $B$ and $C$ the protocol was identical with that on day A except that no vaccination was given.

All subjects ate and behaved normally on the day before an experiment. The vaccination was given immediately before the subjects went to bed and comprised $0.5 \mathrm{ml}$ typhoid-parathyroid A and B and cholera vaccine $B P$ (Wellcome) given subcutaneously. From 1000 the next morning equal portions of food were consumed every two hours until 2000 . Hence the total day's ration, which contained no meat and about $12.9 \mathrm{~g}$ nitrogen and $9.4 \mathrm{MJ}(2.2 \mathrm{kcal})$ energy, was absorbed over about 12 hours. The actual intake for each subject was calculated from food tables. ${ }^{7}$ Oral temperature was measured hourly.

\section{MEASURING PROTEIN TURNOVER RATES WITH ${ }^{15} \mathrm{~N}$-GLYCINE}

Urine was collected between 1000 and 1200 to measure the baseline amount of ${ }^{15} \mathrm{~N}$ in ammonia. At 1200 blood was taken for measurements of urea concentration ${ }^{8}$ and white cell count. Between 1200 and 1300, $91 \mathrm{mg}{ }^{15} \mathrm{~N}$-glycine in $20 \mathrm{ml}$ saline was sterilised by Millipore filtration and then given as a slow intravenous injection. The total urine was collected until 2100 , when another blood sample was taken for measurement of urea concentration. The excretion of ${ }^{15} \mathrm{~N}$ in urinary ammonia and the total excretion of nitrogen, ammonia, and creatinine between 1200 and 2100 were determined as described. ${ }^{9}$ The values for total nitrogen excretion during this time were corrected for changes in the body pool of urea nitrogen. This change was calculated from the change in plasma urea concentration with an assumed body water content of $60 \%$ of body weight.

The excretion of ${ }^{15} \mathrm{~N}$ in urinary ammonia during the nine hours after injection of ${ }^{15} \mathrm{~N}$-glycine was used to calculate the whole-body flux of nitrogen. ${ }^{10-12}$ The nitrogen flux $(\mathrm{Q})$ is defined as the total turnover rate of the body pool of free aminonitrogen, and may be used to calculate the rates of whole-body protein synthesis $(\mathrm{Z})$ and breakdown (B) by using the equation $\mathrm{Q}=\mathrm{E}+\mathrm{Z}=\mathrm{I}+\mathrm{B}$, where $\mathrm{E}$ is the measured rate of urinary nitrogen excretion (corrected for changes in the body urea pool) and I the nitrogen intake during the experiment.

\section{STATISTICAL ANALYSIS}

The significance of differences between values obtained on days $B$ and $C$ and those obtained on day $A$ was assessed by the paired $t$ test. Values in table II were logarithmically transformed for comparison because the effect of vaccination on protein turnover might be expected to be proportional rather than additive. ${ }^{13}$

\section{Results}

In all subjects the body temperature was raised on the day of vaccination (day A), ranging from $37.3^{\circ} \mathrm{C}$ to $38.7^{\circ} \mathrm{C}$. On days $\mathrm{B}$ and $\mathrm{C}$ body temperatures were normal $\left(37 \cdot 1^{\circ} \mathrm{C}\right.$ or less). Similarly, on day A mean white blood cell count increased to $11.9 \pm \mathrm{SD} 2.0 \times 10^{9} / 1$ $\left(11900 \pm 2000 / \mathrm{mm}^{3}\right)$, compared with $6 \cdot 1 \pm 1 \cdot 6 \times 10^{9} / 1(6100 \pm 1600 /$ $\mathrm{mm}^{3}$ ) on day C. On day B the mean count in four of the six subjects was $7 \cdot 7 \pm 0 \cdot 6 \times 10^{9} / 1\left(7700 \pm 600 / \mathrm{mm}^{3}\right)$. Urinary nitrogen excretion during the 24 hours after injection of ${ }^{15} \mathrm{~N}$-glycine was $12.8 \pm \mathrm{SD} 1.4 \mathrm{~g}$ 
on day $\mathrm{A}, 12 \cdot 2 \pm 1.4 \mathrm{~g}$ on day $\mathrm{B}$, and $12 \cdot 1 \pm 1 \cdot 8 \mathrm{~g}$ on day $\mathrm{C}$. The small increase on day $A$ was not significant. The 24 -hour nitrogen intake was the same $(12.9 \mathrm{~g})$ during each of the three experiments. Hence the apparent nitrogen balance (without regard for faecal and integumental losses) was not significantly altered by vaccination. Similarly, urinary nitrogen output during the nine hours after injection of ${ }^{15} \mathrm{~N}$-glycine (corrected for changes in the body urea pool) on day A was not significantly different from the outputs on days B and C (table I).

TABLE I-Mean $( \pm S D)$ rates of nitrogen intake and urinary excretion of nitrogen, ammonia, and creatinine

\begin{tabular}{|c|c|c|c|c|}
\hline Day & $\begin{array}{c}\text { Nitrogen } \\
\text { intake } \\
(\mathrm{g} / 9 \mathrm{~h})\end{array}$ & $\begin{array}{c}\text { Nitrogen } \\
\text { excretion } \\
(\mathrm{g} / 9 \mathrm{~h})\end{array}$ & $\begin{array}{c}\text { Ammonia } \\
\text { excretion } \\
(\mathrm{g} \mathrm{N} / 9 \mathrm{~h})\end{array}$ & $\begin{array}{l}\text { Creatinine } \\
\text { excretion } \\
(\mathrm{mmol} / 9 \mathrm{~h})\end{array}$ \\
\hline $\begin{array}{l}\mathrm{A} \\
\mathrm{B} \\
\mathrm{C}\end{array}$ & $\begin{array}{l}9.7 \pm 0.4 \\
9.7 \pm 0.4 \\
9.7 \pm 0.4\end{array}$ & $\begin{array}{l}6 \cdot 4 \pm 1 \cdot 1 \\
6 \cdot 5 \pm 0.8 \\
6.4 \pm 0.9\end{array}$ & $\begin{array}{l}0.19 \pm 0.04 \\
0.20 \pm 0.04 \\
0.19 \pm 0.05\end{array}$ & $\begin{array}{l}6 \cdot 9 \pm 1 \cdot 5^{*} \\
6 \cdot 5 \pm 1 \cdot 6 \\
6 \cdot 5 \pm 1 \cdot 3^{*}\end{array}$ \\
\hline
\end{tabular}

*Difference between means significant: $\mathrm{p}<0.05$.
Conversion: SI to traditional units-Urinary creatinine: $1 \mathrm{mmol} / 9 \mathrm{~h} \approx 0.11 \mathrm{~g} / 9 \mathrm{~h}$.

During this period the apparent nitrogen balance was positive in all tests because there was a continuous intake of protein from food. This positive nitrogen balance was reversed during the night, when no food was given. ${ }^{14}$ Table I also shows ammonia and creatinine excretions during the nine hours after the administration of isotope. Ammonia excretion was unaltered but the creatinine excretion was higher on the day after vaccination, as may occur in artificially induced hyperthermia. ${ }^{15}$

Table II shows the rates of protein turnover estimated from the excretion of ${ }^{15} \mathrm{~N}$ in ammonia during the nine hours after injection of ${ }^{15} \mathrm{~N}$-glycine. On day A rates of both protein synthesis and breakdown were significantly higher than those measured on day C. Intermediate values were obtained on day $B$. TABLE II-Mean $( \pm S D)$ rates of protein turnover (as $g$
protein $/ 9 h$ )

\begin{tabular}{llll}
\hline & Day A & Day B & Day C \\
\hline Protein synthesis & $81 \pm 30$ & $66 \pm 25^{*}$ & $59 \pm 16^{*}$ \\
Protein breakdown & $62 \pm 30$ & $47 \pm 26$ & $40 \pm 19^{* *}$
\end{tabular}
Significance of differences from mean on day $A:{ }^{*} p<0.05 ;$
${ }^{*} \mathrm{p}<0.01$.

\section{Discussion}

The method adopted for measuring whole-body protein turnover was chosen because it has several merits. Glycine labelled with ${ }^{15} \mathrm{~N}$ is non-radioactive and so may be used repeatedly in subjects of any age. This contrasts with an alternative method -namely, constant infusion of $[1]^{14} \mathrm{C}$-leucine-which is limited to two measurements only in subjects over childbearing age. ${ }^{412}$ The method using ${ }^{15} \mathrm{~N}$-glycine with measurement of urinary ammonia excretion is particularly convenient, since it requires urine to be collected over only nine hours after the injection of isotope. When urinary urea is used for measurements ${ }^{311}$ a much longer period is required for urine collection. Studies on malnourished children and on obese adults have shown that, although the values obtained from measuring urinary ammonia excretion were often lower than with other techniques, the assessment of changes in rates of turnover brought about by dietary manipulation was the same. ${ }^{91112}$ Nevertheless, a change in ammonia production in the kidney might influence the validity of our results. On the day after vaccination, however, the rate of ammonia excretion was no different from that on the other two days (table I). Hence our results probably represent a real stimulation of protein metabolism after vaccination.

Anorexia may be an important complication of infection or trauma. Rates of protein synthesis are acutely responsive to the rate of dietary protein intake, and changes in synthesis may be detected within one to three hours of a change in nitrogen intake. ${ }^{14}$ Our subjects were given a meal every two hours to achieve a reasonably constant rate of nitrogen absorption. Hence the rates of turnover shown in table II apply to fed subjects. Protein synthesis is therefore greater than breakdown, resulting in net retention of nitrogen during the feeding period. Because each subject received the same diet and nitrogen intake during each of the three experiments the observed changes in turnover were not the result of altered food intake, as might occur in an infected patient with anorexia.

Long et $a l^{2}$ measured the rates of protein synthesis and breakdown in three patients with sepsis and in two normal subjects by computer analysis of the curve for excretion of ${ }^{15} \mathrm{~N}$ after a single dose of ${ }^{15} \mathrm{~N}$-alanine. They concluded that, like vaccination, infection increased both synthesis and breakdown. Measurements in individual tissues of infected animals support this conclusion. Although several early studies with labelled amino-acids suggested that in muscle the rate of synthesis was apparently decreased by infection, ${ }^{16}{ }^{17}$ Ryan, using more rigorous methods, showed an increase. ${ }^{18}$ Studies of the rate of excretion of 3methylhistidine in urine also suggested that protein breakdown in infected man is increased. ${ }^{19}$

The increase in whole-body protein turnover with infection or vaccination appears to contrast with reports of the effect of postoperative trauna, when a decrease in whole-body protein synthesis was observed. ${ }^{3} 4$ The importance of this apparent difference is difficult to assess, however, since the protein intake in these studies was lower after operation. This may in itself have resulted in lower rates of protein synthesis. Indeed, measurements of protein synthesis in several tissues of traumatised rats have shown a decrease in synthesis in comparison with uninjured controls when nitrogen was omitted from the diet, but an increase when nitrogen was included. ${ }^{20}$ The increase in protein turnover that we observed after vaccination was, however, independent of any change in nitrogen intake because the same diet was given on each day of measurement.

We also noted that despite a $37 \%$ increase in protein synthesis and a $55 \%$ increase in degradation there was no increase in urinary nitrogen excretion. This differs from the effects of experimental infection ${ }^{1}$ and fever induced by a high environmental temperature. ${ }^{15}$ Vaccination against yellow fever also caused a nitrogen loss from adults given low-protein diets but not when the dietary protein intake was high. ${ }^{5}$ This suggests that considerable changes in protein turnover during infection need not necessarily lead to loss of body protein if the diet is adequate.

We do not know the reasons for the increase in protein turnover, although the increase in body temperature is one possibility. Interestingly, however, rates of protein synthesis and breakdown were still mildly increased between three and six days after vaccination despite the return of body temperature towards normal. Beisel ${ }^{1}$ has drawn attention to the prolonged metabolic disturbances that occur during infection and persist after return of body temperature towards normal. This may be relevant to the weight loss during chronic infections such as tuberculosis or inflammatory bowel disease, in which patients may continue to have weight loss without being feverish. Other features of the anabolic response to infection have been emphasised. ${ }^{1}$

In our study the production of acute-phase proteins from the liver and activation of the immune system are probably important. How much these contribute quantitatively to the increase in whole-body synthesis, however, is unknown.

We thank Miss $H$ Sheppard for technical help and the Wellcome Trust and the Medical Research Council for financial support.

\section{References}

1 Beisel WR. Interrelated changes in host metabolism during generalized infectious illness. Am $\mathcal{F}$ Clin Nutr 1972 ;25:1254-60. 
2 Long CL, Jeevanandam M, Kim BM, Kinney JM. Whole body protein synthesis and catabolism in septic man. Am $\mathcal{f}$ Clin Nutr 1977;30:1340-4.

${ }^{3}$ Crane CW, Picou D, Smith R, Waterlow JC. Protein turnover in patients before and after elective orthopaedic surgery. Brf Surg 1977;64:129-33.

4 O'Keefe SJD, Sender PM, James WPT. Catabolic loss of body nitrogen in response to surgery. Lancet 1974 ;ii:1035-7.

${ }^{5}$ Bistran BR, Winterer JC, Blackburn GL, Scrimshaw NS. Failure of yellow fever immunization to produce a catabolic response in individuals fully adapted to a protein-sparing modified fast. Am $\mathcal{f}$ Clin Nutr 1977; 30:1518-22.

${ }^{6}$ Kielmann AA. Weight fluctuations after immunization in a rural preschool child community. Am $\mathcal{F}$ Clin Nutr 1977;30:592-8.

${ }^{7}$ Paul AA, Southgate DAT. McCance and Widdowson's the composition of foods. 4th ed. London: HMSO, 1978.

8 Fawcett JK, Scott JE. A rapid and precise method for the determination of urea. $\mathcal{F}$ Clin Pathol 1960;13:156-9.

9 Golden MHN, Waterlow JC. Total protein synthesis in elderly people: a comparison of results with $\left({ }^{15} \mathrm{~N}\right)$ glycine and $\left({ }^{14} \mathrm{C}\right)$ leucine. Clin Sci Mol Med $1977 ; 53: 277-88$.

10 Waterlow JC, Garlick PJ, Millward DJ. Protein turnover in mammalian tissues and in the whole body. Amsterdam: North-Holland, 1978:225-99.

11 Waterlow JC, Golden MHN, Garlick PJ. Protein turnover in man measured with ${ }^{15} \mathrm{~N}$ : comparison of end products and dose regimes. Am $\mathcal{F}$ Physiol $1978 ; 235$ :E165-74.
12 Garlick PJ, Clugston GA, Waterlow JC. Influence of low-energy diets on whole-body protein turnover in obese subjects. Am 7 Physiol $1980 ; 238$ : E235-44.

13 Snedecor GW, Cochran WG. Statistical methods. 6th ed. Ames, Iowa: Iowa State University Press, 1967:329.

14 Garlick PJ, Clugston GA, Swick RW, Waterlow JC. Diurnal pattern of protein and energy metabolism in man. Am $\mathfrak{f}$ Clin Nutr (in press).

15 Beisel WR, Goldman RF, Joy RJT. Metabolic balance studies during induced hyperthermia in man. $\mathcal{F} A p p l$ Physiol 1968;24:1-10.

16 Lust G. Effect of infection on protein and nucleic acid synthesis in mammalian organs and tissues. Fed Proc 1966;25:1688-94

17 Young VR, Chen SI, Newberne PM. Effect of infection on skeletal muscle ribosomes in rats fed adequate or low protein. $\mathcal{F}$ Nutr 1968;94:361-8.

${ }^{18}$ Ryan NT. Metabolic adaptations for energy production during trauma and sepsis. Surg Clin North Am 1976;13:1073-90.

19 Long CL, Schiller WR, Blakemore WS, Geiger JW, O'Dell M, Henderson $\mathrm{K}$. Muscle protein catabolism in the septic patient as measured by 3methylhistidine excretion. Am $\mathcal{F}$ Clin Nutr 1977;30:1349-52.

${ }^{20}$ Stein TP, Leskiw MJ, Wallace HW, Oram-Smith JC. Changes in protein synthesis after trauma: importance of nutrition. Am $\mathcal{F}$ Physiol 1977 ;233 : E348-55.

(Accepted 29 May 1980)

\title{
School screening for scoliosis: cohort study of clinical course
}

\author{
ROBERT A DICKSON, PETER STAMPER, ANNE-MARIE SHARP, PAUL HARKER
}

\section{Summary and conclusions}

A visual examination of 1764 Oxford schoolchildren for scoliosis was followed by low-dose radiography of the spine in those who showed evidence of asymmetric body topography; radiography was repeated a year later to assess progression. Forty-four children had curves of $10^{\circ}$ or more. Two had a congenital abnormality and the remaining 42 were classified according to the type of curve: sacral tilt (compensatory), spinal (idiopathic), or combined (sacral tilt and spinal). Progression occurred in $6(14 \%)$ children, none of whom had only a sacral tilt.

These results suggest that only by measuring sacral tilt can benign compensatory curves be differentiated from true idiopathic scoliosis.

\section{Introduction}

Without careful scrutiny of the community most children with progressive scoliosis remain undetected, only to present in later life with permanent disability. ${ }^{1}$ Progression can, however, be prevented by early detection and effective conservative treatment while the deformities are mild and flexible. ${ }^{2}$ Only $10 \%$ of curves detected by screening are progressive, most being nonprogressive lumbar curves. The characteristics of deformities that progress and those that are benign are not clear, but compensatory non-progressive scolioses are commonly produced by a tilt of the sacrum secondary to inequality in the length of the legs. ${ }^{3}$ This cohort study of the clinical course of scoliosis is based on the observation that in many cases of benign scoliosis

Nuffield Department of Orthopaedic Surgery, Nuffield Orthopaedic Centre, Oxford OX3 7LD

ROBERT A DICKSON, CHM, FRCS, clinical reader in orthopaedic surgery PETER STAMPER, FRCR, consultant radiologist

ANNE-MARIE SHARP, MCSP, senior aftercare physiotherapist

PAUL HARKER, MFCM, community physician detected by school screening the curve is compensatory to a tilt of the sacrum but that this tilt is a result of an inherent developmental problem of the pelvis itself rather than any inequality in the length of the legs.

\section{Patients and methods}

A senior physiotherapist experienced in spinal disorders screened 176413 and 14 year olds in five Oxford schools for the presence of a spinal deformity by visual inspection with the patient standing erect and leaning forward (the "one-minute school screening test").4 Those showing evidence of asymmetric body topography were examined with low-dose spinal radiography ${ }^{5}$ in the erect position. The radiographs were measured by Cobb's method, ${ }^{6} 7$ and those children with scolioses of $10^{\circ}$ or more were examined clinically to exclude a musculoskeletal disease as a cause of the deformity. One year later these children were re-examined and radiographs taken using the low-dose technique in the presence of two of us (RAD and PS) to eliminate postural variation.

Examination of the initial standing radiograph showed that many children seemed to have a sacral tilt with reference to the horizontal fluid level in the stomach included in the same radiograph (fig 1). The low-dose spinal radiograph taken at follow-up therefore included a contrast-medium spirit-level ${ }^{8}$ placed on the $x$-ray cassette just below the femoral heads. The site and magnitude of any scoliosis and the sacral tilt were recorded from these films. These data were compared with those of the initial low-dose radiograph to detect progression of the curve (a curve reaching $20^{\circ}$ or more). Significances of differences in the mean size of the curves were confirmed statistically using Student's $t$ test. The relation between magnitude of sacral tilt and magnitude of scoliosis was confirmed by deriving the correlation coefficient, r. Observations concerning proportions of type of scoliosis in different sites in the spine and observations concerning progression were confirmed using the $\chi^{2}$ test.

\section{Results}

Of the 1764 children screened $147(8.3 \%)$ showed evidence of asymmetry of body topography and 121 of these $(6.9 \%)$ had radiographic evidence of a scoliosis. Seventy-seven children (4.3\%) had curves of less than $10^{\circ}$ but $44(2.5 \%)$ had scolioses measuring $10^{\circ}$ or 